\title{
Trophic STATE EVALUATION FOR SELECTED LAKES IN Yellowstone National PARK
}

\author{
WOODRUFF MILLER + CIVIL \& ENVIRONMENTAL ENGINEERING DEPARTMENT \\ BRIGHAM YOUNG UNIVERSITY + PROVO + UT
}

\section{$\uparrow \quad$ INTRODUCTION}

The purpose of this study was to tentatively classify the trophic level for selected lakes, except Yellowstone Lake, in Yellowstone National Park. This paper also documents the monitoring methods and perspectives used in this study as meeting current acceptable practice.

For selected lakes in Yellowstone National Park, phosphorus, nitrogen, chlorophyll-a, and other lake characteristics were studied to identify shortterm lake behavior and to classify the annual average trophic state of the lakes. By studying short-term lake behavior, there may be a greater understanding of how the trophic state of a lake can be averaged annually. Both the annual average trophic state and short-term lake behavior may help to understand the longer term trophic state of a lake.

There is concern that natural processes and human activity on and around the lakes are causing the water quality to decline. We were unable to find any previous studies that defined the trophic state of the lakes. Therefore, an objective of this study is to evaluate the current trophic state of the lakes and develop a preliminary baseline to which future evaluations can be compared.

This study has provided a benchmark trophic state survey not only for comparison to future evaluations, but to identify possible areas of concern. The greater the trophic state, the greater the level of eutrophication that has taken place. As lakes advance in the eutrophication process, water quality generally decreases.

\section{$\downarrow$ MANAGEMENT AND USE IMPLICATIONS AND RECOMMENDATIONS}

A program was formulated for lake monitoring and management. For this project, the program has been written with the intent to document the methods, perspectives, and results of monitoring lakes in Yellowstone National Park. The key components of this program are goals, focuses of study, sampling parameters, sampling techniques, modeling, methods of presenting results, and human use implications and recommendations. This program included procedures that are somewhat new and that may be helpful to standardize and perform future work more effectively.

The major goal of this program is to determine if human activity is causing accelerated eutrophication in selected Yellowstone lakes. Other goals are monitoring of trends, documentation of current trophic conditions, and education of interested professionals as well as interested public.

For this project a focus of study was the correlation of trophic state and algae growth. Algae concentrations are a common monitoring focus because they are one of the most publicly observed (and undesired) lake quality features. Summer is the season of most tourism and is crucial in terms of public concern and impacts. Data and information on algae growth can help to explain short-term variations in lake water nutrient levels and hence fertility. Documentation of variations in nutrients and algae are important for long-term studies of eutrophication. 
Comparing the management of this project with other similar quality programs is important. There are programs at other universities and agencies that are similar to this project. Also, there is a "volunteer movement" in recent lake monitoring history that has been instructive in this project (RISG, 2002).

There have been significant efforts made to monitor lakes in this country. In addition to local, state and federal agencies and universities, involvement from private organizations and citizens has increased over the past two decades. The objectives of these organizations are educational, regulatory and planning.

The task of monitoring lakes is so large that citizen volunteers are needed. The U.S. Environmental Protection Agency (EPA) supports the use of volunteers from the general public to observe national lake water quality. To assist them, the EPA has produced standardized lake monitoring guidelines and techniques. These factors are relevant to our program because this project is somewhat similar to a volunteer monitoring program.

The document "Volunteer Lake Monitoring" produced by the EPA (1991), is a convenient reference for quality control. Another guidance publication is directed towards concerned citizens, and encourages program developments that utilize citizen volunteers and others organized into lake associations. The North American Lake Management Society (NALMS) has prepared "Managing Lakes and Reservoirs" (2001). This text and "Volunteer Lake Monitoring" are comparable in many principles.

The costs and benefits of our project are appropriate for this preliminary effort on important and highly visible lakes where concerns are justified and where problems may be unnoticed. This is certainly the case of the low to moderate eutrophication of lakes in Yellowstone National Park. Our study is intended to determine if human activity in the areas around the lakes has a negative environmental effect relative to eutrophication. The results generally showed that the trophic states ranged widely between oligotrophic and strongly mesotrophic for all lakes. A few lakes were classified as strongly mesotrophic and are therefore of higher priority for future study.

\section{$\uparrow$ EUTROPHICATION}

Eutrophication is the natural aging process of a lake as it progresses from clear and pristine deep water, that does not support much plant or animal life, to more shallow, turbid, and nutrient rich water where plant life and algae is abundant. This process occurs in all lakes happening over a period of thousands of years, the eventual end being the filling of the lake with sediment and the formation of a meadow (Chapra, 1997). Human interaction tends to speed up the eutrophication process by introducing accelerated loadings of nitrogen and phosphorus into aquatic systems.

The trophic state of a lake is a measurement of where the lake is along the eutrophication process. The four main states are explained below (Tchobanoglous, 1985).

\section{TrophIC STATES}

Oligotrophic: The water is clear and devoid of most plants and algae because there are not many nutrients such as nitrogen and phosphorus found in the water. Nevertheless, life is present but in very small numbers.

Mesotrophic: Plant and animal life is abundant and diverse in all forms and in all levels of the food chain.

Eutrophic: The water quality is poor but there still exists an abundance of life. However, there are fewer species and these species are usually of lower quality such as carp rather than trout. Also, there are more algal blooms and slime as well as algal turbidity.

Hyper-eutrophic: The water quality is exceptionally poor with an overabundance of algae and slime. Animal life is similar to the eutrophic state in that there are fewer species.

\section{$\uparrow \quad$ NUTRIENTS AND AlgaE}

Nutrients found in the water are the fuel of the eutrophication process. Phosphorus and nitrogen in the form of nitrate and ammonia are particularly important since they stimulate plant and algae growth. 
Phosphorus and nitrogen enter a wilderness area lake in various ways. One is by leaching from the subsurface bedrock into groundwater that eventually flows into the lake. Another is by tributaries eroding soil and carrying the sediment as well as material from the forest floor into the lake. Animal waste in or around the lake can contribute to the inflow of phosphorus and nitrogen as can human activity. Trash or other waste can enter the lake directly, while hiking or other activities can cause more erosion of the soil which enters the tributaries and ultimately the lake. The human acceleration of the eutrophication process is commonly called cultural eutrophication (Chapra, 1997).

Phosphorus concentrations and algae levels in a lake can fluctuate markedly over time. Comparison of short-term results to annual averages may give insight as to a lake's response to nutrients and how longer-term eutrophication may be progressing.

During the growing season or summer, growth is nurtured by a rise in water temperature. Phosphorus is used by algae and is typically depleted significantly during summer months. Depletion of phosphorus throughout the summer occurs in shallow, mixed lakes. Phosphorus concentrations and algae may increase as a result of storms, which can cause mixing and/or contribute phosphorus loads from eroded soils in the watershed. Some of this phosphorus and nitrogen become available to algae in the photic zone and trigger algae growth (NALMS, 2001).

For this study, one focus was the correlation of trophic state and algae growth. Algae in lakes can be seen and therefore is often of concern by lake users. A national survey in 1998 showed that $44 \%$ of all U.S. lakes contained excessive nutrients that contribute to aquatic growth, especially algae. Data and information on algae growth can help to explain short-term variations in lake water nutrient levels and hence trophic state (NALMS, 2001).

\section{$\downarrow \quad$ TROPHIC STATE INDICATORS}

Four widely used trophic state indicators are the secchi disk transparency, chlorophyll-a levels, total phosphorus and nitrogen. Typically these parameters are all measured and compared to provide valuable information about the relationship between water nutrients and algal growth. The parameters together provide a more complete picture, than if one or more is not included. Guidelines encourage using all four of these indicators (EPA, 1991).

\section{Transparency}

Secchi disk transparency measures water clarity. Water clarity reduces as algal populations grow. Water clarity is important to the public and secchi disk is the most commonly used parameter in citizen monitoring programs. Microorganisms other than algae, suspended sediments, and other dissolved materials that color the water can effect secchi disk measurements. The secchi disk can be misread due to varied lighting and water surface conditions. In some shallow lakes, a secchi disk reading will be inaccurate if the disk reaches the bottom before disappearing from sight (EPA, 1991).

\section{Chlorophyll}

Chlorophyll-a, contained in most algae, is a photosynthetic pigment in the algal cells. Different algal species produce differing amounts of chlorophyll-a. Two lakes can have the same amount of chlorophyll-a, but one have more algae because of a difference in algae species. Chlorophyll-a also varies with light conditions. It increases during the day and decreases at night, and is changed significantly by seasons. The exact amount of algae cannot be determined from the amount of chlorophyll-a. But it is still one of the best "simple" indicators of algal biomass (EPA, 1991).

\section{Phosphorus}

Phosphorus is a measurement of water fertility. Orthophosphate is rapidly used by algae, and hence is often found in low concentrations. Other forms of phosphorus are more dynamic and convert over time to orthophosphate. For these reasons, lakes are tested for total phosphorus (EPA, 1991). For eutrophication analysis, total phosphorus is generally the single most important nutrient to determine when lakes are phosphorus limited (NALMS, 2001).

The initial source of phosphorus is weathering of phosphate-containing rocks. Because phosphorus tends to remain bound to soil particles, drainage from eroded soils carries higher amounts of phosphorus than from vegetated soils. Similarly, surface runoff, with its relatively large content of soil particles, yields higher concentrations of total phosphorus than infiltration water (Harper, 1992). Phosphorus enters lakes as a mixture of dissolved and particulate inputs primarily from streams and rivers. Particulate phosphorus may be deposited in the 
bottom sediments, where much of it is acted upon by micro-bacteria and ultimately converted into dissolved orthophosphate (Correll, 1996).

\section{Nitrogen}

Nitrogen is a common cellular element of living matter and essential to the growth of algae and other forms of aquatic life. It is one of the most important nutrients effecting eutrophication. Although most of the nitrogen in aquatic ecosystems is present as the gas $\mathrm{N}_{2}$, the in-lake nitrogen measured in this study is in the form of nitrate $\left(\mathrm{NO}_{3}{ }^{-}\right)$, nitrite $\left(\mathrm{NO}_{2}{ }^{-}\right)$, or ammonia $\left(\mathrm{NH}_{4}+\right)$. Nitrogen levels were calculated by adding nitrate, nitrite, and ammonia together. Nitrogen in lakes is used by algae for growth and later deposited in the sediments. Nitrogen in algae eaten by zooplankton and insect larvae is excreted as ammonia (Horne, 1994).

The major source of nitrogen for lakes is the nitrate in rainfall which passes directly from the rain in the watershed to the lake via streams or falls directly on the lake. When rain soaks into the ground, nitrate moves freely through soils to the lake. Lakes can have considerable nitrate input from groundwater, especially if the water is contaminated with agricultural nitrate (Horne, 1994).

\section{$\downarrow \quad$ SAMPLING MeTHODS}

Samples were taken in 0.5 liter nalgene bottles and fixed with $2 \mathrm{ml} \mathrm{1:7}$ sulfuric acid. Inlet stream grab samples were taken with care so as to not disturb bottom sediments. Inlet and in-lake samples were analyzed for total phosphorus (TP), while the in-lake samples were also analyzed for chlorophyll-a and nitrogen as nitrate, nitrite, and ammonia. Phosphorus analyses were conducted using the standard EPA No. 365.2 automated ascorbic acid colormetric method. Spectrophotometric chlorophyll analyses were conducted using standard methods No. $10200 \mathrm{H}$. Nitrogen analyses were likewise made with standard methods.

Samples were taken at one or more locations in each lake and in the inlets and outlets. Sampling locations were consistent from lake to lake so that the lakes can be reasonably compared. Samples were taken from the photic zone for chlorophyll-a, total phosphorus, and nitrogen, and were taken at elbow $(\sim 0.5 \mathrm{~m})$ depth. Sampling occurred every one or two months over the spring to fall seasons when the lakes were open and accessible. The information on each field form included monitor's name, name of lake, date, time, weather conditions including cloud cover, air temperature, and human and animal activity in the watershed, map of sampling location, measurement of the secchi disk, and stream flow rate.

\section{$\downarrow \quad$ TrophIC MODELS}

Four models were used in this study to classify the trophic state of the lakes; the Carlson Trophic State Index Model, the Vollenweider Model, the Larsen-Mercier Model, and the NitrogenPhosphorus Ratio Model. Simple models are commonly used where steady-state conditions and lake homogeneity are assumed. Furthermore, the models are spatially and temporally averaged. These assumptions are reasonable for the lakes in this study because these lakes are generally small and likely well mixed. Models based on these assumptions are commonly used because, though simple, they still make useful predictions (NALMS, 2001).

\section{Carlson Trophic State Index}

The Carlson Model utilizes the measurements of three water quality characteristics to graphically estimate an average trophic state. See Figure 1 as an example. The three measurements are transparency, chlorophyll-a, and the total phosphorus concentration in the lake. Each measured value is plotted on a separate logarithmic scale specific to the measured parameter. Then, based upon the value's location in relation to the other measurements on their respective scales, an average can be found that describes the trophic state (Carlson, 1977).

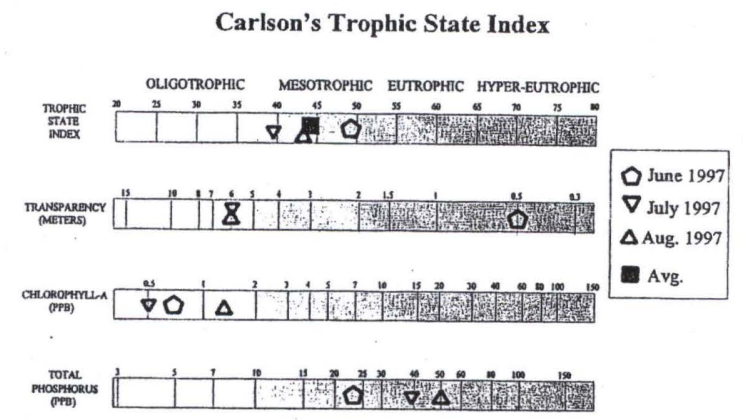

Figure 1: Example of Carlson's Model

In this study, the transparency depths of the lakes are not included in the Carlson Model. This is because the depths were not measured but only estimated, or the lakes were too shallow. Therefore, the trophic state is based upon the graphical average of the chlorophyll-a and the phosphorus concentrations. 
The Carlson's Trophic State Index (TSI) is the most widely used trophic state indicator and may be used in the process of lake protection and restoration (NALMS, 2001). The measurements found from sampling the characteristics are applied to TSI equations to determine TSI values. The TSI values are classified according to trophic state.

The equations for TSI values are (NALMS, 2001):

TSI $($ Secchi disk $)=60-14.41 * \ln$ (depth in meters)

TSI (Chlorophyll-a) $=30.6+$ $9.81 * \ln ($ concentration in $\mathrm{ug} / \mathrm{L}$ )

TSI (Total Phosphorus) $=4.15+$ $14.42 * \ln ($ concentration in $\mathrm{ug} / \mathrm{L}$ )

The TSI equation for nitrogen is (NALMS, 2001):

TSI $($ Nitrogen $)=4.45+14.43 * \ln$ (concentration in ug/L)

Usually TSI values are classified as follows: Mesotrophic for $40<=$ TSI $<=50$, Eutrophic for TSI $>50$ and Oligotrophic for TSI $<40$ (EPA, 1991). For this study, the TSI values were also classified as: Strongly Oligotrophic, Oligotrophic, Slightly Oligotrophic, Slightly Mesotrophic, Mesotrophic, Strongly Mesotrophic, Slightly Eutrophic, Eutrophic, Strongly Eutrophic, and Hyper-Eutrophic (see Table 1). These subdivisions are a means of creating a finer classification of the trophic state of the lake to give an idea of how close it is to the next trophic state.

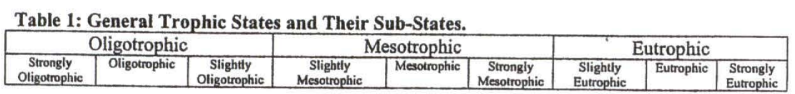

The Carlson phosphorus TSI is generally valid for lakes that are phosphorus limited. This index is expected to not work as well in lakes that are nitrogen-limited, or turbid due to suspended sediments, or when excessive macrophytes (macroscopic plants) are present.

The TSI values can be plotted in order to understand seasonal patterns, to compare the three TSI parameters, and to classify the trophic state of the lakes. The TSI results for the individual parameters (phosphorus, chlorophyll-a, clarity) may not compare well, or may not be close to the same values because unique conditions may exist. For example, a large growth of zooplankton may suppress the algae, thus lowering the chlorophyll-a, while the TSI for phosphorus remains high. Another example is a secchi disk TSI that is extremely high due to sediment turbidity.

\section{$\downarrow \quad$ VOLLENWEIDER MODEL}

The Vollenweider Model is based upon the phosphorus availability to the lake. It utilizes measurements of the total inflowing phosphorus concentration plotted against the hydraulic residence time of the lake. The hydraulic residence time is the average outflow divided into the volume of the lake. The location of the values on the graph determines the trophic state of the lake (Vollenweider, 1968). See Figure 2 as an example.

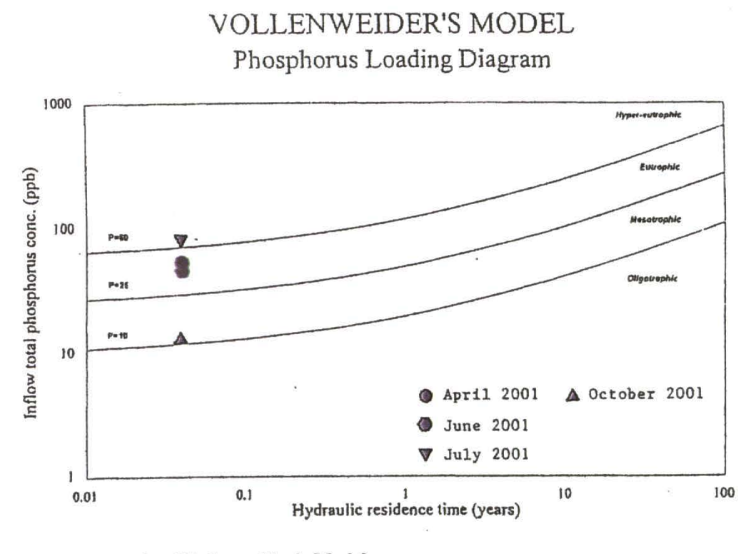

Figure 2: Example of Vollenweider's Model

The volumes of Shoshone, Lewis, and Heart Lakes, the largest lakes, were determined using lake bottom contour maps provided by Yellowstone National Park. The volumes of all other smaller lakes were estimated.

\section{$\downarrow \quad$ LARSEN-MERCIER MODEL}

The Larsen-Mercier Model uses the measurements of the total inflowing phosphorus concentration plotted against the phosphorus retention coefficient (Larsen and Mercier, 1975). See Figure 3 as an example. This retention coefficient is calculated by the following equation.

Phosphorus Retention Coefficient $=P_{I N} Q_{I N}-P_{\text {OUT }} Q_{\text {OUT }}$

$$
P_{I N} Q_{I N}
$$

where: 
$P_{I N}=$ phosphorus concentration in the inflow

$Q_{I N}=$ flow rate of incoming water

$P_{\text {OUT }}=$ phosphorus concentration in the outflow

$Q_{\text {OUT }}=$ flow rate of outflowing water

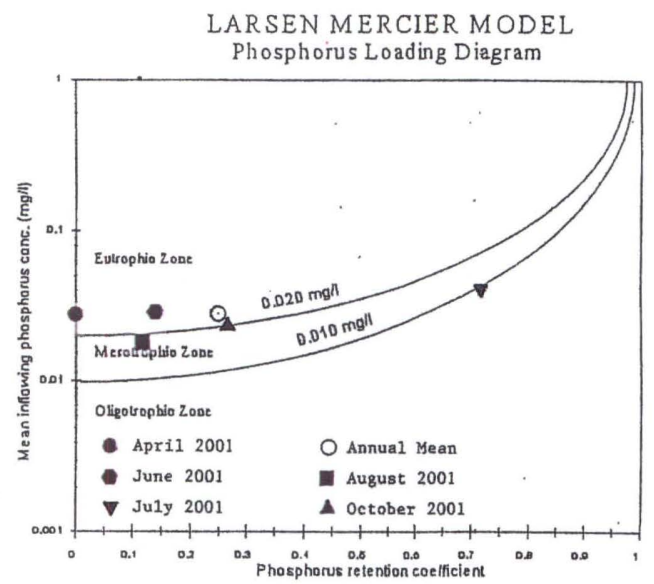

Figure 3: Example of Larsen-Mercier's Model

In this model, sometimes the average phosphorus concentration in the lake water was used to estimate the outflow phosphorus concentration. This is a safe assumption for small lakes that typically have small hydraulic residence times, but may not work as well for larger lakes with longer residence times.

The Vollenweider's Model and the LarsenMercier Model used for this study utilize the following fundamental variables: inflowing and outflowing phosphorus concentrations, lake volumes, and the flows of water into and out of the lakes. These models utilize variables typical to simple lake models. These models also appear to have potential to be used to study forecasts. Internally loaded phosphorus is generally considered moderate in using the Vollenweider and the Larsen-Mercier Models.

\section{The Nitrogen-Phosphorus Ratio}

While there are many nutrients necessary for algae growth, nitrogen and/or phosphorus tend to be present in the most limiting amounts. The assessment of the limiting nutrient is important, because control of the limiting nutrient can inhibit algal growth.

The nitrogen-phosphorus (N:P) ratio is commonly used to determine whether nitrogen or phosphorus is the limiting nutrient. In theory, an N:P ratio less than 7 implies that nitrogen is more likely to be limiting. Conversely, an N:P ratio greater than 7 implies that phosphorus is more likely to be limiting.
The value of 7 should not be applied too strictly, however. In practice, phosphorus is considered limiting if the $\mathrm{N}: \mathrm{P}$ ratio is greater than 10 , nitrogen is considered limiting if the N:P ratio is less than 5, and both phosphorus and nitrogen are considered limiting if the N:P ratio is between 5 and $10(\mathrm{Li}, 1995)$.

The nitrogen-phosphorus (N:P) ratios were calculated for each lake. Some of these lakes were determined to be more nitrogen-limited than phosphorus-limited. Nitrogen was measured at less than $0.15 \mathrm{mg} / \mathrm{L}$ for almost all the lakes. This result came from: $\mathrm{NO} 2+\mathrm{NO} 3, \mathrm{~N}<0.1 \mathrm{mg} / 1$ and ammonia, $\mathrm{N}<$ $0.05 \mathrm{mg} / \mathrm{l}$. Therefore, the given N:P ratio for each lake is the highest possible value, while the actual ratio is likely to be some value lower. Because the value of $0.15 \mathrm{mg} / \mathrm{L}$ was used for nitrogen in measuring the N:P ratio for almost all lakes, changes in the calculated N:P ratios are mainly due to changes in phosphorus levels.

\section{LARGE LAKES IN SOUTH YELLOWSTONE PARK}

This paper will first present the results for large lakes (except Yellowstone Lake) in south Yellowstone Park which were studied in 1999.

\section{Shoshone Lake}

Shoshone Lake is located approximately six miles to the southwest of the West Thumb of Yellowstone Lake and approximately eight miles southeast of Old Faithful (see Figure 4). It sits at an elevation of 7791 feet above sea level and is a naturally pristine lake with clear water that can reach down to 200 feet in depth. The surface area is approximately 8100 acres and the approximate volume is 778,000 acre-ft.

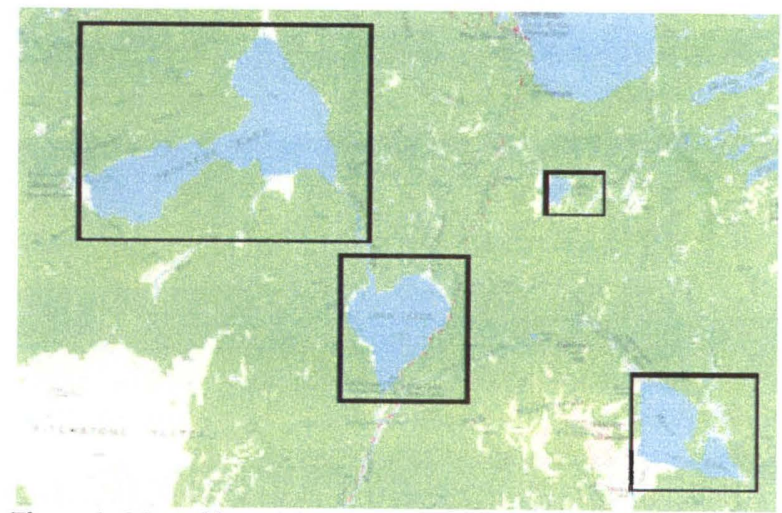

Figure 4. Map of large lakes in South Yellowstone Park 
Shoshone Lake has several inflowing creeks around its perimeter but the three main tributaries are Moose Creek, DeLacy Creek, and Shoshone Creek. These three contribute over $90 \%$ of the water flowing into the lake. Measurements were taken on DeLacy Creek and Shoshone Creek while flow in Moose Creek was estimated based upon watershed area. Lewis River is the only outlet of the lake and it flows all year long. During the spring and summer months it typically flows at or above $250 \mathrm{cfs}$ and during the winter months, while frozen over, it flows at about flows at about $90 \mathrm{cfs}$.

Water samples were taken from the lake at three different locations. The first was on the northeast side of the lake near DeLacy Creek, the second was on the west side of the lake near Shoshone Creek, and the third was on the southeast side of the lake near the Lewis River outlet. The results of the model analysis over the summer months show that Shoshone Lake on the average is mesotrophic at DeLacy Creek, while it is slightly oligotrophic at Shoshone Creek. On the southeast side near the outlet, the lake is also slightly oligotrophic. The lake as a whole is classified as slightly mesotrophic with the exception of near DeLacy Creek (see Table 2). DeLacy Creek and the lake near DeLacy Creek are a cause for concern because of their higher phosphorus input and trophic state, respectively. They should be monitored in the future.

Table 2: Large Lakes Trophic States According to each of the Three Models
\begin{tabular}{|l|c|}
\hline \multicolumn{1}{|c|}{ Model } & Classification \\
\hline Shoshone Lake & \\
Carlson & Slightly Mesotrophic \\
Vollenweider & Slightly Mesotrophic \\
Larsen-Mercier & Mesotrophic \\
Shoshone Lake Average & Slightly Mesotrophic \\
\hline Lewis Lake & Slightly Mesotrophic \\
Carlson & Slightly Mesotrophic \\
Vollenweider & Slightly Mesotrophic \\
Larsen-Mercier & Slightly Mesotrophic \\
Lewis Lake Average & Slightly Oligotrophic \\
\hline Heart Lake & Slightly Oligotrophic) \\
Carlson & Mesotrophic \\
Vollenweider & Slightly Mesotrophic \\
Larsen-Mercier & Heart Lake Average
\end{tabular}

The nitrogen-phosphorus ratio at Shoshone Lake locations show the lake as phosphorus limited except for the August sample near DeLacy Creek which is nitrogen limited (see Table 3).

\section{Lewis Lake}

Lewis Lake sits at an elevation of 7,779 feet above sea level and is about three miles to the southeast of Shoshone Lake (see Figure 4). It has a surface area of 2,700 acres and an approximate volume of 121,000 acre- $\mathrm{ft}$. The depth is 100 feet at the center, but in the western quarter of the lake the depth is no more than ten feet. The main inlets to the lake are Lewis River which flows from Shoshone Lake, Dogshead Creek, and some seasonal tributaries. Lewis River flows at an average of about $250 \mathrm{cfs}$ during the spring and summer months, and at an average of about $90 \mathrm{cfs}$ during the winter.

Flow measurements and sampling of Lewis River and Dogshead Creek were made near the inlets in June, July, and August. Other seasonal tributary flows were estimated based upon their watersheds. The only outlet from Lewis Lake is the Lewis River at the south point of the lake. Lake samples were taken off the boat dock near the outlet. Other lake samples were taken from the northeast side and the middle north side.

The results of sampling over the summer show that on average the lake at Dogshead Creek is mesotrophic. The lake on the middle north side near the Lewis River inlet is slightly mesotrophic and the sampling off the boat dock also shows the lake slightly mesotrophic. The lake as a whole is classified as slightly mesotrophic (see Table 2). Attention should be paid to the Dogshead Creek area since the highest trophic state in the lake is found there.

The nitrogen-phosphorus ratio for all samples taken from Lewis Lake show the lake as phosphorus limited with the exception of the July sample taken from the middle north side (see Table 3 ). Therefore, the lake is generally phosphorus limited.

\begin{tabular}{|c|c|c|}
\hline Location & Date & Ratio \\
\hline \multicolumn{3}{|l|}{ Shoshone Lake } \\
\hline \multirow{2}{*}{ DeLacy Creek (Northeast Side) } & June & 10.00 \\
\hline & August & 0.31 \\
\hline \multirow{3}{*}{ Near Outlet (Southeast Side) } & July & 19.33 \\
\hline & July & 16.67 \\
\hline & August & 8.33 \\
\hline Shoshone Lake Average & & 10.9 \\
\hline \multicolumn{3}{|l|}{ Lewis Lake } \\
\hline \multirow[t]{2}{*}{ Dogshead Creek (Northeast Side) } & June & 9.38 \\
\hline & August & 12.50 \\
\hline \multirow{2}{*}{ Lewis River (Middle North Side) } & July & 4.17 \\
\hline & August & 12.50 \\
\hline \multirow[t]{2}{*}{ Boat Dock Near Outlet (South Side) } & June & 10.71 \\
\hline & August & 13.64 \\
\hline Lewis Lake Average & & 10.5 \\
\hline \multicolumn{3}{|l|}{ Heart Lake } \\
\hline \multirow[t]{2}{*}{ Witch Creek (Northwest Side) } & July & 13.64 \\
\hline & August & 11.54 \\
\hline \multirow{2}{*}{ Witch Creek (Southwest Side) } & July & 10.00 \\
\hline & August & 10.71 \\
\hline Heart Lake Average & & 11.5 \\
\hline
\end{tabular}

\section{Heart Lake}

Heart Lake is located about six miles to the southeast of Lewis Lake and about seven miles south of Yellowstone Lake (see Figure 4). The lake sits at an elevation of 7,450 feet above sea level. It has a surface area of approximately 2,500 acres with an approximate volume of 125,000 acre- $\mathrm{ft}$ and a 
maximum depth of 180 feet. Heart Lake's eastern bay is very shallow with depths less than 10 feet and no deeper than 20 feet.

The major inflowing streams are Witch Creek, Beaver Creek, and some seasonal tributaries. The only outlet is the Heart River which flows at an annual average flow of $100 \mathrm{cfs}$. During the spring and summer, Heart River flows at an average of about $250 \mathrm{cfs}$ but during the winter the river is frozen over and only flows at about $50 \mathrm{cfs}$.

The results of the summer sampling near Witch Creek show that Heart Lake on the average is slightly mesotrophic. Results on the northwest wide of the lake are slightly oligotrophic while on the southwest side they are slightly mesotrophic. Although we classified the lake as a whole as slightly mesotrophic, samples were not taken on the east side of the lake, which might yield a somewhat different classification (see Table 2).

All samples taken from Heart Lake show algae production as phosphorus limited because of nitrogen-phosphorus ratios that are greater than 7 (see Table 3).

\section{Riddle Lake}

Riddle Lake is located about 2 miles south of the West Thumb of Yellowstone Lake (see Figure 4). It has a surface area of approximately 240 acres and a volume of approximately 4,800 acre-ft. The inflowing streams are seasonal. They have an estimated total flow of approximately $10-15 \mathrm{cfs}$ during the spring but dry up by August. The outflowing stream, Solution Creek, flows into Yellowstone Lake at approximately the same flow rate as the inflows.

Based on the results of one lake sample, Riddle Lake is classified as mesotrophic. The nitrogen-phosphorus ratio is 10.7 , which means that the algae is phosphorus limited.

\section{SUMMARY}

In this study, four large lakes in south Yellowstone National Park were evaluated: Shoshone Lake, Lewis Lake, Heart Lake, and Riddle Lake. The Carlson Trophic State Index, the Vollenweider
Model, the Larsen-Mercier Model, and the NitrogenPhosphorus Ratio Model were used to evaluate the trophic states. The trophic states established in this study will be useful as a preliminary evaluation to which future studies can be compared.

Shoshone Lake is slightly oligotrophic except the bay area near DeLacy Creek which is mesotrophic. Lewis Lake is generally slightly mesotrophic except near Dogshead Creek. Heart Lake is slightly mesotrophic and Riddle Lake is mesotrophic. Nitrogen-phosphorus ratio results show that generally the lakes are phosphorus limited.

It is recommended that future studies sample all lake tributaries and outlets and measure their flowrates. Also, samples should be taken from farther off shore in the lake where any contamination with bottom sediments can be avoided and transparency depths can be measured. Winter and late fall sampling should be done when there is less usage of the park so as to more fully understand how much of an impact human activity has on the trophic states of the lakes.

\section{Mid-sized Lakes in Central Yellowstone Park}

This paper will next present the results for selected mid-sized lakes in Yellowstone National Park. Water samples were also taken from four lakes in the Canyon-Norris area of Yellowstone National Park, namely: Cascade Lake, Grebe Lake, Ice Lake, and Wolf Lake. These lakes are shown on Figure 5. The water samples were taken during the months of June, July, August, and October of 2000.

The results of the water sample analyses were plotted on the models. Evaluation of the models led to the classification or the trophic state of each lake. These trophic results are given in Table 4. The determinations for the classifications are given in the following paragraphs.

\section{Cascade Lake}

Cascade Lake is strongly mesotrophic according to the Carlson Model. According to the Vollenweider Model, the lake is mesotrophic and is strongly mesotrophic according to the LarsenMercier Model. Overall, Cascade Lake is classified as strongly mesotrophic. 


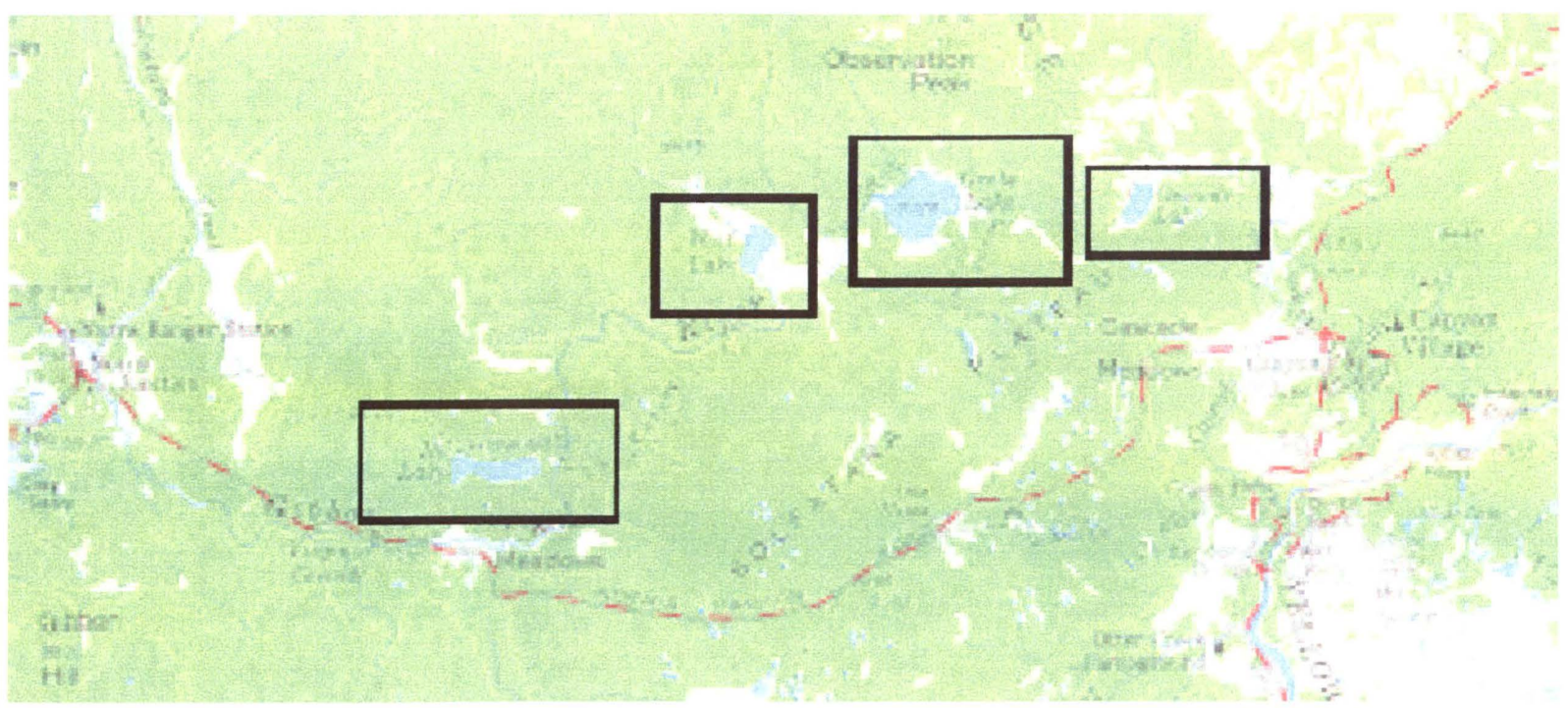

Figure 5. Map of Mid-sized Lakes in Central Yellowstone Park,

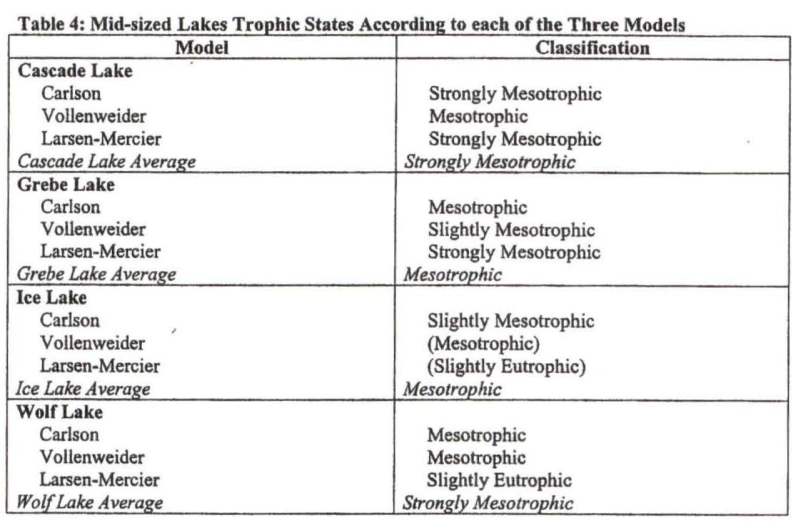

Grebe Lake

Grebe Lake is mesotrophic according to the Carlson Model. It is slightly mesotrophic in July, but strongly mesotrophic in August. According to the Vollenweider Model, the lake is strongly oligotrophic in July but mesotrophic in August, with an average of slightly mesotrophic. Based on the Larsen-Mercier Model, Grebe Lake is mesotrophic in July but slightly eutrophic in August. The overall classification for Grebe Lake is mesotrophic (see Table 4).

\section{Ice Lake}

Ice Lake is slightly mesotrophic on Carlson's Model. The Vollenweider model shows that the lake is slightly mesotrophic in June and October, and mesotrophic in August. On the other hand, the Larsen-Mercier Model shows that Ice Lake is slightly eutrophic in June, eutrophic in August, and strongly mesotrophic in October. These two models do not agree very well. This is apparently because the inflow phosphorus concentrations for the Vollenweider and Larsen-Mercier came from very small inlets flows. Consequently, more emphasis is given to the Carlson Model. Therefore, the average overall classification for Ice Lake is considered to be mesotrophic (see Table 4).

\section{Wolf Lake}

On the Carlson Model, Wolf Lake ranges between slightly mesotrophic and slightly eutrophic, in July and August respectively. Meanwhile, the Vollenweider Model suggests that the lake is mesotrophic and the Larsen-Mercier Model suggests it is strongly mesotrophic to slightly eutrophic. The overall classification for Wolf Lake is strongly mesotrophic (Table 4).

\section{$\uparrow \quad$ SUMMARY}

The N:P ratios for Cascade, Ice, Grebe, and Wolf Lakes indicate that none of the lakes is strictly phosphorus limited. Grebe and Wolf Lakes are considered nitrogen limited. Cascade and Ice Lakes may be nitrogen limited, if actual nitrogen levels are significantly below the detection limit of $0.15 \mathrm{mg} / \mathrm{L}$ (see Table 5). 


\begin{tabular}{|c|c|c|c|}
\hline & Location & Date & Ratio \\
\hline $\begin{array}{c}\text { Cascade Lake } \\
\text { East Side } \\
\text { West Side }\end{array}$ & $\begin{array}{r}\text { East Side Average } \\
\text { West Side Average } \\
\text { Cascade Lake Average }\end{array}$ & $\begin{array}{c}\text { June } \\
\text { August } \\
\text { October } \\
\text { June } \\
\text { August } \\
\text { October }\end{array}$ & $\begin{array}{l}5.4 \\
9.6 \\
7.7 \\
7.5 \\
6.1 \\
5.3 \\
10.1 \\
7.2 \\
7.3 \\
\end{array}$ \\
\hline \begin{tabular}{|l} 
Ice Lake \\
North Side \\
\\
South Side
\end{tabular} & $\begin{array}{l}\text { North Side Average } \\
\text { South Side Average } \\
\text { Ice Lake Average }\end{array}$ & $\begin{array}{c}\text { June } \\
\text { August } \\
\text { October } \\
\text { June } \\
\text { August } \\
\text { October }\end{array}$ & \begin{tabular}{|l|}
4.3 \\
4.7 \\
12.0 \\
7.0 \\
7.1 \\
8.0 \\
9.3 \\
8.1 \\
7.6 \\
\end{tabular} \\
\hline $\begin{array}{c}\text { Grebe Lake } \\
\text { East Side } \\
\text { West Side }\end{array}$ & Grebe Lake Average & $\begin{array}{l}\text { August } \\
\text { August }\end{array}$ & \begin{tabular}{|l}
6.6 \\
4.6 \\
5.6 \\
\end{tabular} \\
\hline $\begin{array}{l}\text { Wolf Lake } \\
\text { South Side } \\
\text { North Side }\end{array}$ & Wolf Lake Average & $\begin{array}{l}\text { August } \\
\text { August }\end{array}$ & $\begin{array}{l}4.2 \\
6.1 \\
5.1 \\
\end{array}$ \\
\hline
\end{tabular}

Grebe Lake, as mesotrophic, appears to be in good trophic condition, although the August phosphorus is quite high. Ice Lake also appears to be in good trophic condition based mainly on the Carlson Model and discounting the Larsen-Mercier results. There is some concern for Cascade and Wolf Lakes as strongly mesotrophic. Wolf Lake in August, as slightly eutrophic, was in the worst condition and should be studied further.

While trophic state determination varied from month to month and from lake to lake, the water quality of the lakes is generally mesotrophic. This means that while the lakes have experienced some eutrophication, water quality as measured by trophic state is fairly good. It will be useful to compare these results with past and future studies in order to determine the effects of human interaction on these lakes.

\section{Small Lakes in Western Yellowstone Park}

Finally, this paper presents the results for other smaller selected lakes in Yellowstone National Park, namely: South Nymph Lake, Nymph Lake, South Twin Lake, North Twin Lake, Beaver Lake, Swan Lake, Harlequin Lake, Goose Lake, Blacktail Pond, and Lake of the Woods (see Figures 6 and 7). The water samples were taken during the months of April, June, July, August and October of 2001 and were generally only taken at one location at each lake.

The average annual trophic state is determined for each lake. The Carlson TSI, Vollenweider's Model, and the Larsen-Mercier
Model are weighted equally and averaged together resulting in a final overall trophic state. First, the parameters of the Carlson TSI are weighted equally and averaged, resulting in a trophic state for each month sampled. Then these monthly results are averaged to an annual average. Next, the monthly outcomes of the Vollenweider's Model are averaged. Lastly, the annual averages of these three models are averaged to one overall annual trophic state of the lake.

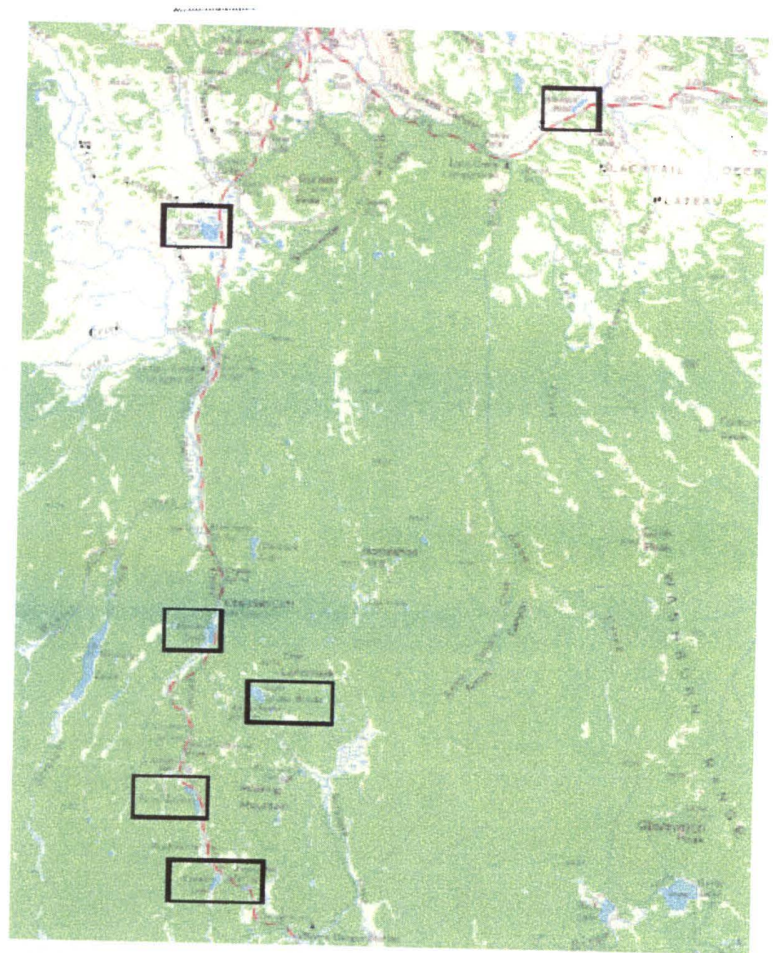

Figure 6. Map of Small Lakes in Northwest Yellowstone Park

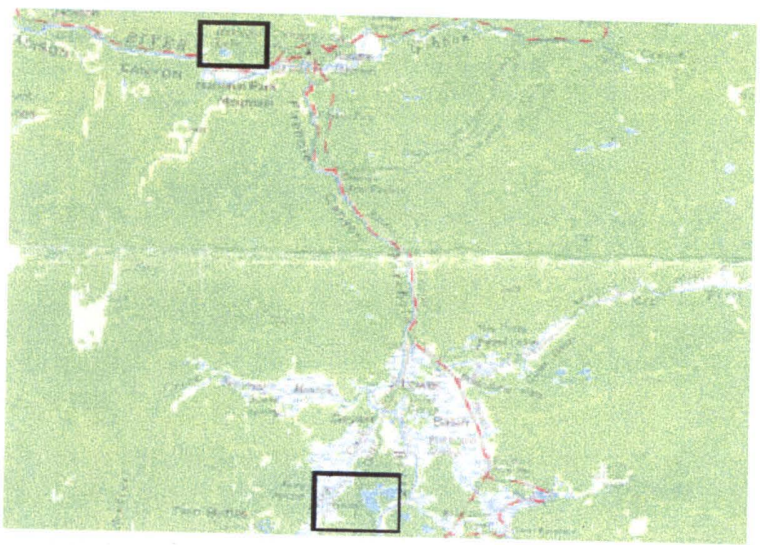

Figure 7. Map of small Lakes in Southwest Yellowstone Park. 
South Nymph Lake

For South Nymph Lake, the Carlson TSI indicates that the lake was slightly mesotrophic. The Vollenweider's Model and the Larsen-Mercier Model show that the lake was slightly eutrophic. The overall trophic state of the lake was therefore determined to be mesotrophic (see Table 6). The lake is shallow with an average depth of estimated at $3 \mathrm{ft}$.

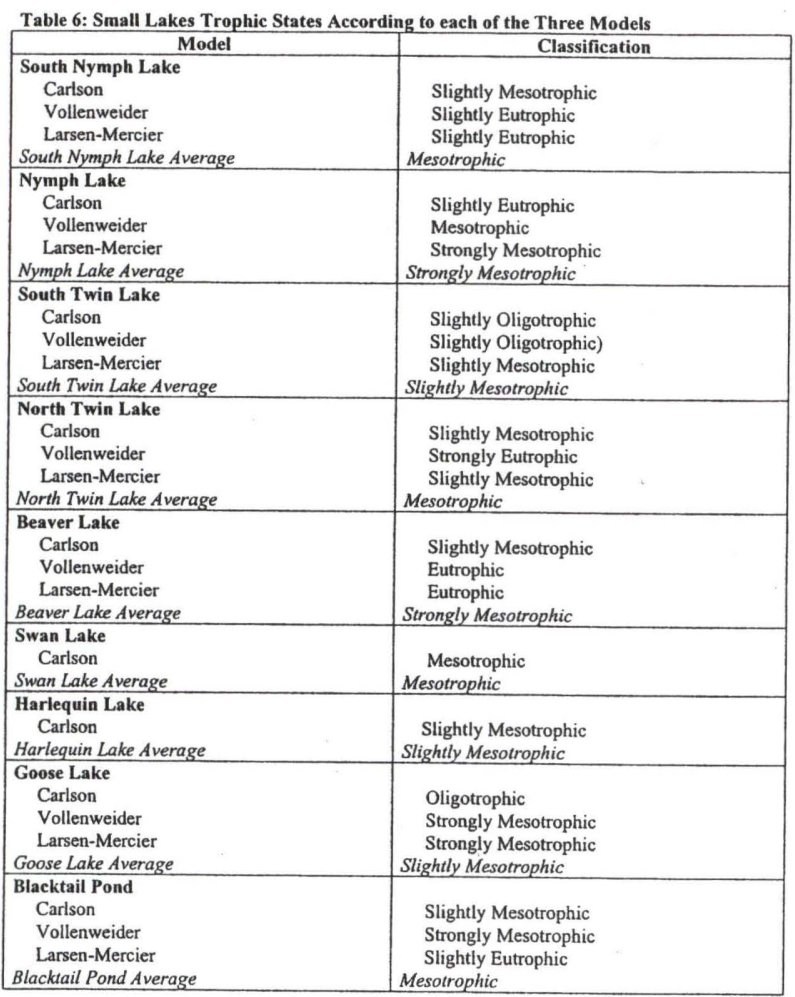

Nymph Lake

The Carlson TSI indicates that Nymph Lake was slightly eutrophic. The Vollenweider's Model shows that the lake was mesotrophic. The LarsenMercier Model shows that the lake was strongly mesotrophic. The overall trophic state of the lake was therefore determined to be strongly mesotrophic (see Table 6).

For Nymph lake it is not clear why there is high phosphorus in the lake in August and October samples. The average depth of Nymph Lake was estimated at $4 \mathrm{ft}$. Perhaps this high loading is the result of run-off from late summer and fall storms. A trophic state of strongly mesotrophic seems high for this lake. The inflowing phosphorus samples appear to show that the watershed generally contributes a lesser load for this lake than others.
South Twin Lake

The Carlson TSI and Vollenweider Model indicate that South Twin Lake was slightly oligotrophic. The Larsen-Mercier Model shows that the lake was strongly mesotrophic. The overall trophic state of the lake was determined to be slightly mesotrophic (see Table 6).

\section{North Twin Lake}

For North Twin Lake, the Carlson TSI and Larsen-Mercier indicate that the lake was slightly mesotrophic. The Vollenweider's Model shows that the lake was strongly eutrophic. The overall trophic state of the lake was therefore determined to be mesotrophic despite the hyper-eutrophic Vollenweider values (see Table 6).

\section{Beaver Lake}

The Carlson TSI indicates that Beaver Lake was slightly mesotrophic. The Vollenweider's Model and the Larsen-Mercier Model both show that the lake was eutrophic. The overall trophic state of the lake was determined to be strongly mesotrophic (see Table 6).

\section{Swan Lake}

The Carlson TSI indicates that Swan Lake was mesotrophic. There is no inlet stream to Swan lake, so the Vollenweider's and Larsen-Mercier models were not applied. The lake was too low to be able to take an October sample. The overall trophic state of the lake was determined to be mesotrophic (see Table 6).

\section{Harlequin Lake}

The Carlson TSI indicates that Harlequin Lake (see Figure 7) was slightly mesotrophic. There is also no inlet steam to Harlequin Lake, so the Vollenweider's and Larsen-Mercier models were not applied. No April or October samples were taken. The overall trophic state of the lake was determined to be slightly mesotrophic (see Table 6).

\section{Goose Lake}

The Carlson TSI indicates that Goose Lake was oligotrophic. The Vollenweider's Model and the Larsen-Mercier Model both show that the lake was strongly mesotrophic. Only one water sample was taken, in July. Based on this limited data the overall 


\section{Blacktail Pond}

The Carlson TSI indicates that Blacktail Pond (see Figure 6) was slightly mesotrophic. Blacktail Pond does not have an inlet stream, but in July an "inlet seep" was sampled. The Vollenweider's Model shows that the lake was strongly mesotrophic. The Larsen-Mercier Model shows that the lake was slightly eutrophic. No June sample was taken because of bird protection. The overall trophic state of the pond was therefore determined to be mesotrophic (see Table 6).

\section{Lake of the Woods}

For Lake of the Woods, only one water sample was taken, in June. The Carlson TSI indicates that the lake was strongly mesotrophic. There is no inlet stream to Lake of the Woods, so the Vollenweider's and Larsen-Mercier models were not applied. Based on this very limited data the trophic state of the lake was determined to be strongly mesotrophic.

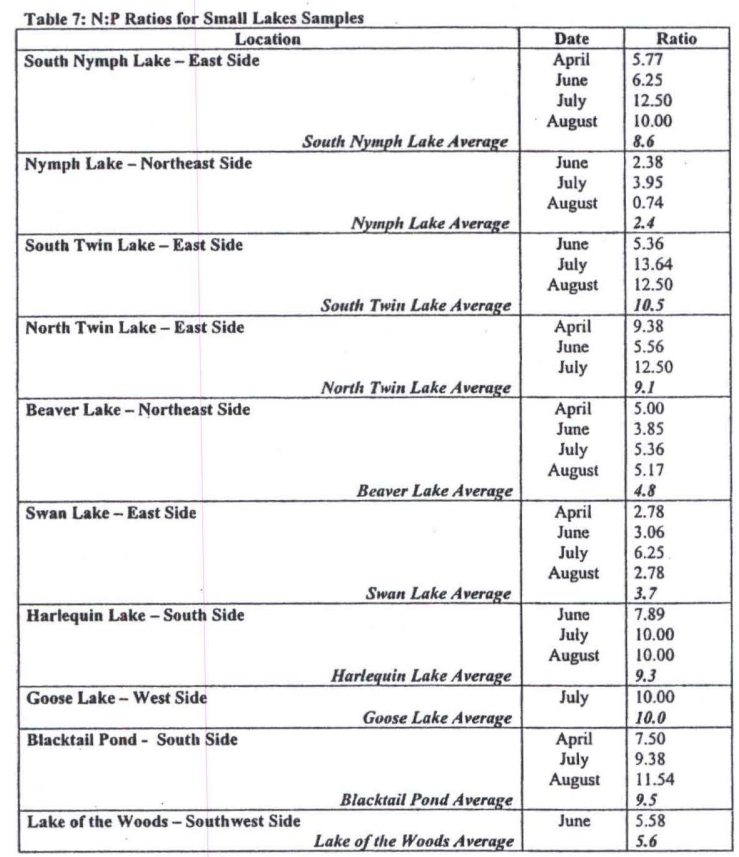

\section{SUMMARY}

The nitrogen-phosphorus $(\mathrm{N}: \mathrm{P})$ ratios were calculated for each lake (see Table 7). The following is an example calculation of the N:P ratio for Nymph Lake for June:

$0.1 \mathrm{mg} / 1(\mathrm{NO} 2+\mathrm{NO} 3, \mathrm{~N})+0.05 \mathrm{mg} / 1$ $($ ammonia, $\mathrm{N})=0.15 \mathrm{mg} / 1$
$0.15 \mathrm{mg} / 1 / 0.063 \mathrm{mg} / 1$ (phosphorus) $=2.38$

Nymph Lake's ratios were always below 5 . Ratios of Beaver Lake and Swan Lake were both below 5 and between 5 and 10, and seemed to lean towards nitrogen-limited conditions. Ratios of South Nymph Lake, North Twin Lake, Harlequin Lake, and Blacktail Pond appear to indicate that they could equally be either nitrogen-limited or phosphoruslimited. The ratios of South Twin Lake appear to lean toward phosphorus-limited conditions.

The previous tables showed the lakes' trophic state results. Nymph Lake was classified strongly mesotrophic because of the high in-lake total phosphorus, and should be of concern. Beaver Lake was also classified strongly mesotrophic and should be of concern. There is still a possibility that due to nitrogen-limited conditions, the eutrophication of these two lakes is less severe. The strongly mesotrophic state of Lake of the Woods was determined from only one sample. Therefore, this lake needs further study in order to determine if it is of concern. Data is also scarce for Goose Lake. The trophic states of the remainder of the lakes are based on several samples and are not of concern.

\section{$\downarrow \quad$ REFERENCES}

Carlson, Robert E. (1977). “A Trophic State Index for Lakes," Limnology and Oceanography. Vol. 22, No. 2, pp. 361-369.

Chapra, Steven C. (1997). Surface Water-Quality Modeling. McGraw-Hill, Inc., New York.

Correll, D.L. (1998). "The role of phosphorus in the eutrophication of receiving waters: a review," Journal of Environmental Quality. Madison, WI, 27 (2), 261-266.

Environmental Protection Agency (EPA) (1991). Volunteer Lake Monitoring. JT\&A, Inc.

Harper, D. (1992). Eutrophication of Freshwater. Chapman and Hall, New York, NY, 36-53.

Horne, A.J. and C. R. Goldman (1994). Limnology. McGraw-Hill, Inc., New York, NY, 133150. 
Larsen, D.P. and H.T. Mercier (1975)."Lake Phosphorus Loading Graphs: An Alternative," Working Paper \#174. Pacific Northwest Environmental Research Lab, EPA, Corvallis, Oregon.

Li, C.C. (1995). "Eutrophication of two lakes in Kinmen Island (Taiwan)." Chemistry and Ecology, London, England, 3 (1), 61-63.

North American Lake Management Society (NALMS) (2001). Managing Lakes and Reservoirs. Terrene Institute.
Rhode Island Sea Grant (RISG) (2002). "09-04 Volunteers Help Monitor U.S. Coastal Zone." Environmental Quality, News Releases.

Tchobanoglous, George, and Edward D. Schroeder (1985). Water Quality. Addison-Wesley.

Vollenweider, R.A. Sc. (1968). "Fundamentals of the eutrophication of lakes and flowing water, with particular reference to $\mathrm{N}$ and $\mathrm{P}$ as factors in eutrophication." Technical Report OECH, Paris, France, DAS/CSI/68.27. 


\begin{tabular}{|c|c|c|c|c|c|c|c|}
\hline \multicolumn{8}{|c|}{ Appendix: Yellowstone Lakes Lab \& Field Results } \\
\hline Location & Date & $\begin{array}{c}\text { Total } \\
\text { Phosphorus } \\
\text { (mg/L) }\end{array}$ & $\begin{array}{l}\mathrm{NO} 2+\mathrm{NO} 3 \\
\text { Nitrogen } \\
(\mathrm{mg} / \mathrm{L})\end{array}$ & $\begin{array}{l}\text { Ammonia } \\
\text { Nitrogen } \\
(\mathrm{mg} / \mathrm{L})\end{array}$ & $\begin{array}{c}\text { Chlorophylla } \\
\mathrm{a} \\
(\mathrm{ppb})\end{array}$ & $\begin{array}{l}\text { Estimated } \\
\text { Secchi } \\
\text { Depth } \\
\text { (m) }\end{array}$ & $\begin{array}{l}\text { Approximate } \\
\text { Flow Rate } \\
\text { (cfs) }\end{array}$ \\
\hline $\begin{array}{l}\text { Large Lakes } \\
\text { Shoshone Lake } \\
\text { Northeast Side }\end{array}$ & $\begin{array}{l}09 / 06 / 98 \\
06 / 22 / 99 \\
08 / 16 / 99 \\
\end{array}$ & $\begin{array}{l}0.036 \\
0.015 \\
0.478 \\
\end{array}$ & $\begin{array}{l}<0.1 \\
<0.1\end{array}$ & $\begin{array}{l}<0.05 \\
<0.05 \\
\end{array}$ & $\begin{array}{l}1.1 \\
1.0 \\
1.3\end{array}$ & $\begin{array}{l}\sim 6 \\
\sim 6 \\
6-8 \\
\end{array}$ & \\
\hline West Side & $07 / 17 / 99$ & 0.015 & $<0.1$ & 0.19 & 0.5 & $6-8$ & \\
\hline Southeast Side & $\begin{array}{l}07 / 30 / 99 \\
08 / 19 / 99 \\
\end{array}$ & $\begin{array}{l}0.009 \\
0.018\end{array}$ & $\begin{array}{l}<0.1 \\
<0.1\end{array}$ & $\begin{array}{l}<0.05 \\
<0.05\end{array}$ & $\begin{array}{l}1.7 \\
1.4\end{array}$ & $\begin{array}{l}6-8 \\
6-8 \\
\end{array}$ & \\
\hline $\begin{array}{l}\text { De Lacy } \\
\text { Creek (Inlet) }\end{array}$ & $\begin{array}{l}06 / 22 / 99 \\
08 / 16 / 99 \\
\end{array}$ & $\begin{array}{l}0.026 \\
0.074 \\
\end{array}$ & & & & & $\begin{array}{l}200 \\
8 \\
\end{array}$ \\
\hline $\begin{array}{l}\text { Shoshone } \\
\text { Creek (Inlet) }\end{array}$ & $07 / 17 / 99$ & 0.013 & & & & & 65 \\
\hline $\begin{array}{l}\text { Lewis River } \\
\text { (Outlet) }\end{array}$ & $\begin{array}{l}07 / 30 / 99 \\
08 / 19 / 99\end{array}$ & $\begin{array}{l}0.011 \\
0.018\end{array}$ & $<0.1$ & $<0.05$ & 1.4 & & $\begin{array}{l}200 \\
200\end{array}$ \\
\hline $\begin{array}{l}\text { Lewis Lake } \\
\text { Southeast Side }\end{array}$ & $\begin{array}{l}09 / 08 / 98 \\
06 / 22 / 99 \\
08 / 19 / 99 \\
\end{array}$ & $\begin{array}{l}0.020 \\
0.014 \\
0.011 \\
\end{array}$ & $\begin{array}{l}<0.1 \\
<0.1\end{array}$ & $\begin{array}{l}<0.05 \\
<0.05\end{array}$ & $\begin{array}{l}1.3 \\
1.9 \\
1.1 \\
\end{array}$ & $\begin{array}{l}\sim 6 \\
\sim 6 \\
6-8 \\
\end{array}$ & \\
\hline Northeast Side & $\begin{array}{l}06 / 22 / 99 \\
08 / 19 / 99\end{array}$ & $\begin{array}{l}0.016 \\
0.012\end{array}$ & $\begin{array}{l}<0.1 \\
<0.1\end{array}$ & $\begin{array}{l}<0.05 \\
<0.05\end{array}$ & $\begin{array}{l}0.7 \\
2.9\end{array}$ & $\begin{array}{l}\sim 6 \\
6-8\end{array}$ & \\
\hline North Side & $\begin{array}{l}07 / 30 / 99 \\
08 / 19 / 99 \\
\end{array}$ & $\begin{array}{l}0.036 \\
0.012 \\
\end{array}$ & $\begin{array}{l}<0.1 \\
<0.1\end{array}$ & $\begin{array}{l}<0.05 \\
<0.05\end{array}$ & $\begin{array}{l}0.9 \\
1.7\end{array}$ & $\begin{array}{l}6-8 \\
6-8 \\
\end{array}$ & \\
\hline $\begin{array}{l}\text { Lewis River } \\
\text { (Inlet) }\end{array}$ & $\begin{array}{l}07 / 30 / 99 \\
08 / 19 / 99 \\
\end{array}$ & $\begin{array}{l}0.010 \\
0.017 \\
\end{array}$ & & & & & $\begin{array}{l}250 \\
220 \\
\end{array}$ \\
\hline $\begin{array}{l}\text { Dogshead } \\
\text { Creek (Inlet) }\end{array}$ & $\begin{array}{l}06 / 20 / 99 \\
08 / 19 / 99\end{array}$ & $\begin{array}{l}0.016 \\
0.041\end{array}$ & & & & & $\begin{array}{l}5 \\
1\end{array}$ \\
\hline $\begin{array}{l}\text { Heart Lake } \\
\text { Northwest } \\
\text { Side }\end{array}$ & $\begin{array}{l}07 / 18 / 99 \\
08 / 19 / 99 \\
\end{array}$ & $\begin{array}{l}0.011 \\
0.013 \\
\end{array}$ & $\begin{array}{l}<0.1 \\
<0.1\end{array}$ & $\begin{array}{l}<0.05 \\
<0.05\end{array}$ & $\begin{array}{l}<0.5 \\
1.5 \\
\end{array}$ & $\begin{array}{l}6-8 \\
6-8 \\
\end{array}$ & \\
\hline $\begin{array}{l}\text { Southwest } \\
\text { Side }\end{array}$ & $\begin{array}{l}07 / 18 / 99 \\
08 / 19 / 99 \\
\end{array}$ & $\begin{array}{l}0.015 \\
0.014 \\
\end{array}$ & $\begin{array}{l}<0.1 \\
<0.1\end{array}$ & $\begin{array}{l}<0.05 \\
<0.05\end{array}$ & $\begin{array}{l}1.5 \\
4.4 \\
\end{array}$ & $\begin{array}{l}6-8 \\
6-8 \\
\end{array}$ & \\
\hline $\begin{array}{l}\text { Witch Creek } \\
\text { (Inlet) }\end{array}$ & $\begin{array}{l}07 / 18 / 99 \\
08 / 19 / 99 \\
\end{array}$ & $\begin{array}{l}0.013 \\
0.024 \\
\end{array}$ & & & & & $\begin{array}{l}40 \\
25 \\
\end{array}$ \\
\hline $\begin{array}{c}\text { Riddle Lake } \\
\text { North Side } \\
\end{array}$ & $08 / 17 / 99$ & 0.014 & $<0.1$ & $<0.05$ & 4.1 & $6-8$ & \\
\hline $\begin{array}{l}\text { Mid-sized Lakes } \\
\text { Cascade Lake } \\
\text { East Side }\end{array}$ & $\begin{array}{l}06 / 17 / 00 \\
08 / 20 / 00 \\
10 / 06 / 00\end{array}$ & $\begin{array}{l}0.028 \\
0.016 \\
0.020 \\
\end{array}$ & $\begin{array}{l}<0.1 \\
<0.1 \\
0.1\end{array}$ & $\begin{array}{l}<0.05 \\
<0.05 \\
<0.05\end{array}$ & $\begin{array}{l}7.2 \\
3.8 \\
9.3\end{array}$ & $\begin{array}{l}1-2 \\
2-3 \\
\sim 5 \\
\end{array}$ & \\
\hline West Side & $\begin{array}{l}06 / 17 / 00 \\
08 / 20 / 00 \\
10 / 06 / 00\end{array}$ & $\begin{array}{l}0.025 \\
0.028 \\
0.015 \\
\end{array}$ & $\begin{array}{l}0.1 \\
<0.1 \\
0.1 \\
\end{array}$ & $\begin{array}{l}<0.05 \\
<0.05 \\
<0.05\end{array}$ & $\begin{array}{l}4.1 \\
3.2 \\
3.1 \\
\end{array}$ & $\begin{array}{l}2-3 \\
2-3 \\
\sim 5\end{array}$ & \\
\hline $\begin{array}{l}\text { Cascade } \\
\text { Creek (Inlet) }\end{array}$ & $\begin{array}{l}06 / 17 / 00 \\
08 / 20 / 00 \\
10 / 06 / 00\end{array}$ & $\begin{array}{l}0.023 \\
0.030 \\
0.015\end{array}$ & & & & & $\begin{array}{l}2 \\
1 \\
2\end{array}$ \\
\hline $\begin{array}{l}\text { Cascade } \\
\text { Creek (Outlet) }\end{array}$ & $\begin{array}{l}06 / 17 / 00 \\
10 / 06 / 00 \\
\end{array}$ & $\begin{array}{l}0.040 \\
0.029 \\
\end{array}$ & & & & & $\begin{array}{l}2 \\
2\end{array}$ \\
\hline $\begin{array}{l}\text { Grebe Lake } \\
\text { East Side }\end{array}$ & $\begin{array}{l}07 / 29 / 00 \\
08 / 20 / 00\end{array}$ & 0.023 & $<0.1$ & $<0.05$ & $\begin{array}{l}3.6 \\
4.7\end{array}$ & $2-3$ & \\
\hline West Side & $\begin{array}{l}07 / 29 / 00 \\
08 / 20 / 00\end{array}$ & 0.033 & $<0.1$ & $<0.05$ & $\begin{array}{l}1.9 \\
6.7\end{array}$ & $2-3$ & \\
\hline $\begin{array}{l}\text { Gibbon River } \\
\text { (Inlet) }\end{array}$ & $\begin{array}{l}07 / 29 / 00 \\
08 / 20 / 00\end{array}$ & $\begin{array}{l}0.016 \\
0.042 \\
\end{array}$ & & & & & $\begin{array}{l}10 \\
1\end{array}$ \\
\hline $\begin{array}{l}\text { Ice Lake } \\
\text { North Side }\end{array}$ & $\begin{array}{l}06 / 17 / 00 \\
08 / 20 / 00 \\
10 / 06 / 00\end{array}$ & $\begin{array}{l}0.035 \\
0.032 \\
0.013\end{array}$ & $\begin{array}{l}<0.1 \\
<0.1 \\
0.1\end{array}$ & $\begin{array}{l}<0.05 \\
<0.05 \\
<0.05\end{array}$ & $\begin{array}{l}1.7 \\
2.4 \\
2.4\end{array}$ & $\begin{array}{l}2-3 \\
\sim 5 \\
\sim 5\end{array}$ & \\
\hline South Side & $\begin{array}{l}06 / 17 / 00 \\
08 / 20 / 00 \\
10 / 06 / 00 \\
\end{array}$ & $\begin{array}{l}0.021 \\
0.019 \\
0.016 \\
\end{array}$ & $\begin{array}{l}<0.1 \\
<0.1 \\
0.1\end{array}$ & $\begin{array}{l}<0.05 \\
<0.05 \\
<0.05\end{array}$ & $\begin{array}{l}1.2 \\
1.8 \\
2.2 \\
\end{array}$ & $\begin{array}{l}2-3 \\
\sim 5 \\
\sim 5 \\
\end{array}$ & \\
\hline
\end{tabular}




\begin{tabular}{|c|c|c|c|c|c|c|c|}
\hline \multicolumn{8}{|c|}{ Appendix: Yellowstone Lakes Lab \& Field Results } \\
\hline Seeps (Inlet) & $\begin{array}{l}06 / 17 / 00 \\
08 / 20 / 00 \\
10 / 06 / 00\end{array}$ & $\begin{array}{l}0.025 \\
0.035 \\
0.023 \\
\end{array}$ & & & & & $\begin{array}{l}0.01 \\
0.01 \\
0.01\end{array}$ \\
\hline $\begin{array}{l}\text { Wolf Lake } \\
\text { South Side }\end{array}$ & $\begin{array}{l}07 / 29 / 00 \\
08 / 20 / 00\end{array}$ & 0.036 & $<0.1$ & $<0.05$ & $\begin{array}{l}2.0 \\
3.9\end{array}$ & $2-3$ & \\
\hline North Side & $\begin{array}{l}07 / 29 / 00 \\
08 / 20 / 00\end{array}$ & 0.025 & $<0.1$ & $<0.05$ & $\begin{array}{l}2.0 \\
20.7\end{array}$ & $2-3$ & \\
\hline $\begin{array}{l}\text { Gibbon River } \\
\text { (Inlet) }\end{array}$ & $\begin{array}{l}07 / 29 / 00 \\
08 / 20 / 00\end{array}$ & $\begin{array}{l}0.019 \\
0.026\end{array}$ & & & & & $\begin{array}{l}10 \\
3\end{array}$ \\
\hline $\begin{array}{l}\text { Small Lakes } \\
\text { South Nymph } \\
\text { Lake } \\
\text { South Side }\end{array}$ & $\begin{array}{l}04 / 29 / 01 \\
06 / 21 / 01 \\
07 / 15 / 01 \\
08 / 23 / 01 \\
10 / 07 / 01 \\
\end{array}$ & $\begin{array}{l}0.026 \\
0.024 \\
0.012 \\
0.015 \\
0.016\end{array}$ & $\begin{array}{l}0.1 \\
0.1 \\
0.1 \\
0.1 \\
0.1 \\
\end{array}$ & $\begin{array}{l}0.05 \\
0.05 \\
0.05 \\
0.05\end{array}$ & $\begin{array}{l}1.8 \\
0.2 \\
1.9\end{array}$ & $\begin{array}{l}2-3 \\
2-3 \\
2-3 \\
\sim 2 \\
1-2\end{array}$ & \\
\hline Seeps (Inlet) & $\begin{array}{l}04 / 29 / 01 \\
06 / 21 / 01 \\
07 / 15 / 01 \\
08 / 23 / 01 \\
10 / 07 / 01 \\
\end{array}$ & $\begin{array}{l}0.026 \\
0.028 \\
0.042 \\
0.017 \\
0.022 \\
\end{array}$ & & & & & $\begin{array}{l}2 \\
1 \\
1 \\
0.5 \\
0.2 \\
\end{array}$ \\
\hline $\begin{array}{l}\text { Nymph Lake } \\
\text { East Side }\end{array}$ & $\begin{array}{l}04 / 30 / 01 \\
06 / 21 / 01 \\
07 / 15 / 01 \\
08 / 23 / 01 \\
10 / 07 / 01 \\
\end{array}$ & $\begin{array}{l}0.065 \\
0.038 \\
0.203 \\
0.130\end{array}$ & $\begin{array}{l}0.1 \\
0.1 \\
0.1\end{array}$ & $\begin{array}{l}0.05 \\
0.05\end{array}$ & $\begin{array}{l}1.2 \\
2.4 \\
4.7\end{array}$ & $\begin{array}{l}\sim 3 \\
2-3 \\
\sim 1 \\
\sim 0.2 \\
\sim 0.2\end{array}$ & \\
\hline $\begin{array}{l}\text { Nymph Creek } \\
\text { (Inlet) }\end{array}$ & $\begin{array}{l}04 / 30 / 01 \\
06 / 21 / 01 \\
07 / 15 / 01 \\
08 / 23 / 01 \\
10 / 07 / 01 \\
\end{array}$ & $\begin{array}{l}0.020 \\
0.016 \\
0.022 \\
0.010 \\
0.016\end{array}$ & & & & & $\begin{array}{l}5 \\
3 \\
2 \\
1.5 \\
1 \\
\end{array}$ \\
\hline $\begin{array}{l}\text { South Twin } \\
\text { Lake } \\
\text { East Side }\end{array}$ & $\begin{array}{l}04 / 30 / 01 \\
06 / 21 / 01 \\
07 / 15 / 01 \\
08 / 23 / 01 \\
10 / 07 / 01\end{array}$ & $\begin{array}{l}0.028 \\
0.011 \\
0.012 \\
0.016\end{array}$ & $\begin{array}{l}0.1 \\
0.1 \\
0.1 \\
0.1 \\
\end{array}$ & $\begin{array}{l}0.05 \\
0.05 \\
0.05\end{array}$ & $\begin{array}{l}2.5 \\
0.8\end{array}$ & $\begin{array}{l}\sim 3 \\
2-3 \\
3-4 \\
2-3 \\
2-3\end{array}$ & \\
\hline $\begin{array}{l}\text { North Twin } \\
\text { Lake } \\
\text { East Side }\end{array}$ & $\begin{array}{l}04 / 29 / 01 \\
06 / 21 / 01 \\
07 / 15 / 01 \\
08 / 23 / 01 \\
10 / 07 / 01 \\
\end{array}$ & $\begin{array}{l}0.016 \\
0.027 \\
0.012 \\
0.010 \\
0.016 \\
\end{array}$ & $\begin{array}{l}0.1 \\
<0.1 \\
<0.1 \\
<0.1 \\
<0.1\end{array}$ & $\begin{array}{l}0.05 \\
<0.05 \\
<0.05 \\
<0.05\end{array}$ & $\begin{array}{l}3.1 \\
1.1\end{array}$ & $\begin{array}{l}3-4 \\
2-3 \\
2-3 \\
2-3 \\
2-3\end{array}$ & \\
\hline Creek (Inlet) & $\begin{array}{l}04 / 29 / 01 \\
06 / 21 / 01 \\
08 / 23 / 01 \\
10 / 07 / 01 \\
\end{array}$ & $\begin{array}{l}0.071 \\
0.113 \\
0.070 \\
0.070 \\
\end{array}$ & & & & & $\begin{array}{l}2 \\
0.5 \\
0.4 \\
0.3 \\
\end{array}$ \\
\hline $\begin{array}{l}\text { Beaver Lake } \\
\text { East Side }\end{array}$ & $\begin{array}{l}04 / 30 / 01 \\
06 / 21 / 01 \\
07 / 15 / 01 \\
08 / 23 / 01 \\
10 / 07 / 01\end{array}$ & $\begin{array}{l}0.030 \\
0.039 \\
0.028 \\
0.029 \\
0.020\end{array}$ & $\begin{array}{l}<0.1 \\
<0.1 \\
<0.1 \\
0.1 \\
<0.1\end{array}$ & $\begin{array}{l}<0.05 \\
<0.05 \\
<0.05 \\
0.05\end{array}$ & $\begin{array}{l}3.4 \\
0.5 \\
1.2 \\
0.2\end{array}$ & $\begin{array}{l}2-3 \\
\sim 1 \\
\sim 2 \\
\sim 2 \\
\sim 1\end{array}$ & \\
\hline $\begin{array}{l}\text { Obsidian } \\
\text { Creek (Inlet) }\end{array}$ & $\begin{array}{l}04 / 30 / 01 \\
06 / 21 / 01 \\
07 / 15 / 01 \\
08 / 23 / 01 \\
10 / 07 / 01\end{array}$ & $\begin{array}{l}0.050 \\
0.043 \\
0.075 \\
0.001 \\
0.012\end{array}$ & & & & & $\begin{array}{l}3 \\
0.3 \\
0.2 \\
2 \\
1\end{array}$ \\
\hline
\end{tabular}




\begin{tabular}{|c|c|c|c|c|c|c|c|}
\hline \multicolumn{8}{|c|}{ Appendix: Yellowstone Lakes Lab \& Field Results } \\
\hline $\begin{array}{c}\text { Swan Lake } \\
\text { East Side }\end{array}$ & $\begin{array}{l}04 / 29 / 01 \\
06 / 21 / 01 \\
07 / 15 / 01 \\
08 / 23 / 01 \\
\end{array}$ & $\begin{array}{l}0.054 \\
0.049 \\
0.024 \\
0.054\end{array}$ & $\begin{array}{l}<0.1 \\
<0.1 \\
<0.1 \\
<0.1\end{array}$ & $\begin{array}{l}<0.05 \\
<0.05 \\
<0.05 \\
<0.05\end{array}$ & $\begin{array}{l}4.3 \\
2.4 \\
0.5 \\
0.3\end{array}$ & $\begin{array}{l}2-3 \\
2-3 \\
3-4 \\
\sim 2 \\
\end{array}$ & \\
\hline $\begin{array}{l}\text { Harlequin Lake } \\
\text { South Side }\end{array}$ & $\begin{array}{l}06 / 23 / 01 \\
07 / 15 / 01 \\
08 / 23 / 01\end{array}$ & $\begin{array}{l}0.019 \\
0.015 \\
0.015\end{array}$ & $\begin{array}{l}<0.1 \\
<0.1 \\
<0.1\end{array}$ & $\begin{array}{l}<0.05 \\
<0.05 \\
<0.05\end{array}$ & $\begin{array}{l}7.3 \\
1.4 \\
0.4\end{array}$ & $\begin{array}{l}2-3 \\
2-3 \\
\sim 2\end{array}$ & \\
\hline $\begin{array}{c}\text { Goose Lake } \\
\text { West Side }\end{array}$ & $07 / 14 / 01$ & 0.015 & $<0.1$ & $<0.05$ & & $3-4$ & \\
\hline Creek (Inlet) & $07 / 14 / 01$ & 0.024 & & & & & 2 \\
\hline $\begin{array}{l}\text { Blacktail Pond } \\
\text { South Side }\end{array}$ & $\begin{array}{l}04 / 29 / 01 \\
07 / 15 / 01 \\
08 / 23 / 01 \\
10 / 07 / 01\end{array}$ & $\begin{array}{l}0.020 \\
0.016 \\
0.013 \\
0.014 \\
\end{array}$ & $\begin{array}{l}<0.1 \\
<0.1 \\
<0.1 \\
<0.1\end{array}$ & $\begin{array}{l}<0.05 \\
<0.05 \\
<0.05\end{array}$ & $\begin{array}{l}2.8 \\
0.7\end{array}$ & $\begin{array}{l}3-4 \\
3-4 \\
\sim 2 \\
2-3\end{array}$ & \\
\hline Seeps (Inlet) & $07 / 15 / 01$ & 0.026 & & & & & 0.01 \\
\hline $\begin{array}{c}\text { Duck Lake } \\
\text { East Side }\end{array}$ & $\begin{array}{l}06 / 23 / 99 \\
08 / 21 / 99\end{array}$ & $\begin{array}{l}0.015 \\
0.013\end{array}$ & $\begin{array}{l}<0.1 \\
<0.1\end{array}$ & $\begin{array}{l}<0.05 \\
<0.05\end{array}$ & $\begin{array}{l}0.5 \\
1.9\end{array}$ & $\begin{array}{l}\sim 5 \\
\sim 5\end{array}$ & \\
\hline
\end{tabular}

